\title{
SISTEM PENDUKUNG KEPUTUSAN LOMBA KINERJA KELURAHAN DENGAN METODE AHPDI KOTA BOGOR
}

\author{
Fitri Mulyani ${ }^{1}$, Hj. Ir. Suratun ${ }^{2}$, Puspa Eosina ${ }^{3}$ \\ Universitas Ibn Khaldun Bogor \\ Jl. K. H. Sholeh Iskandar Km. 2 Kedung Badak Bogor 16162 \\ Email:mulyani@gmail.com
}

\begin{abstract}
ABSTRAK
Badan Pemberdayaan Masyarakat dan Keluarga Berencana (BPMKB) Kota Bogorsetiap tahunnya melaksanakan lomba kinerja kelurahan melalui proses perlombaan kelurahan, yaitu untuk mengevaluasi tingkat keberhasilan pembangunan dikelurahan dengan kriteria-kriteria tertentu dalam penyeleksiannya. Berdasarkan hasil wawancara dan observasi lapangan penyelenggaraan perlombaan dilakukan melalui tiga jenis seleksi yaitu seleksi administrasi, seleksi presentasi (ekspos) dan seleksi kunjungan lapang dengan mengacu pada Peraturan Menteri Dalam Negeri nomor 13 tahun 2007 tentang penyelenggaraan perlombaan desa dan kelurahan. Untuk seleksi administrasi sudah ada aturan dan sistem tersendiri untuk menghitung hasil skor penilaian, sedangkan dalam penentuan penetapan pemenang lomba kinerja kelurahan dinilai pada seleksi presentasi dan kunjungan lapang masih menghitung secara manual sehingga dibutuhkan Sistem pendukung Keputusan (SPK) yang mampu memberikan solusi alternatif untuk penilaian presentasi dan kunjungan lapang. Metode yang digunakan dalam sistem pendukung keputusan lomba kinerja kelurahan menggunakan metode Analytical Hierarchy Process (AHP) untuk pembobotan kriteria dan alternatif. Perancangan SPK lomba kinerja menggunakanModel SDLC. Model SDLC terdiri atas perencanaan, analisis, perancangan, implementasi, pengujian, dan pemeliharaan. SPK menggunakan 3 jenis hak akses (roles) yaitu admin, juri dan pimpinan. Keluaran sistem disajikan dalam bentuk hasil angka perhitungan AHP yang dapat dipertimbangkan lebih lanjut oleh pihak pengambil keputusan. Sistem pendukung keputusan dibangun menggunakan Database Managament System (DBMS) MySQL Xampp dan bahasa pemrograman PHP. Pengujian sistem menggunakan Black-Box Testing. Berdasarkan hasil perhitungan diperoleh hasil perhitungan bobot kriteria yaitu : 0,1667 untuk kriteria penguasaan materi ekspos, 0,0556 untuk kriteria penampilanpemberi materi ekspos, 0,1111 untuk kriteria ketepatan waktu ekspos, 0,2222 untuk kriteria produk unggulan, dan 0,4444 untuk kriteria inovasi, sedangkanhasil perhitungan alternatif urutan ranking terbaik yaitu kelurahan Menteng, kelurahan Cibadak, kelurahan Ciparigi, kelurahan Katulampa, kelurahan Cikaret, dan kelurahan Babakan Pasar.
\end{abstract}

Kata kunci: Sistem Pendukung Keputusan, Lomba Kinerja Kelurahan, MetodeAnalytical Hierarchy Process (AHP), SDLC, Black-Box Testing.

\section{ABSTRACT}

The Bogor City Community Empowerment and Family Planning Agency (BPMKB) annually conducts village performance competitions through the village competition process, which is to evaluate the success rate of development in the urban village with certain criteria in its selection.Based on the results of interviews and field observations, the competition was conducted through three types of selection, namely administrative selection, presentation selection (exposure) and field visit selection with reference to the Regulation of the Minister of Home Affairs number 13 of 2007 concerning the implementation of village and sub-district competitions. For the administrative selection, there are already separate rules and systems for calculating the results of the assessment scores, while in determining the winner of the village performance competition, it is assessed in the presentation selection and field visits still counting manually so a Decision Support System (SPK) is needed that is able to provide alternative solutions for presentation assessment. and field visits. The method used in the decision support system for village performance competitions uses the Analytical Hierarchy Process (AHP) method for weighting criteria and alternatives. The design of the performance competition DSS uses the SDLC Model. The SDLC model consists of planning, analysis, design, 
implementation, testing, and maintenance. SPK uses 3 types of access rights (roles), namely admin, jury and leadership. The system output is presented in the form of AHP calculation results which can be considered further by the decision maker. The decision support system was built using the MySQL Xampp Database Management System (DBMS) and the PHP programming language. System testing using Black-Box Testing. Based on the results of the calculation, the results of the calculation of the weight of the criteria are: 0.1667 for the criteria for mastery of the exposed material, 0.0556 for the appearance criteria for giving the exposed material, 0.1111 for the criteria for timeliness of exposure, 0.2222 for the superior product criteria, and 0.4444 for the innovation criteria, while the results of the calculation of the best ranking alternatives are Menteng village, Cibadak village, Ciparigi village, Katulampa village, Cikaret village, and Babakan Pasar village.

Keywords: Decision Support System, Kelurahan Performance Competition, Analytical Hierarchy Process (AHP) Method, SDLC, Black-Box Testing.

\section{PENDAHULUAN}

Kemampuan untuk mengambil keputusan yang cepat, Perlombaan kelurahan tepat dan akurat akan menjadi kunci keberhasilan dalam persaingan global saat ini. Banyak informasi yang dimiliki tidak cukup bila informasi tersebut tidak digunakan dengan baik. Informasi dapat berguna bila dimanfaatkan dengan baik, bahkan jika diolah oleh suatu sistem maka informasi tersebut dapat berdaya guna dengan baik. Sistem yang mengolah informasi salah-satunya sistem pendukung keputusan, sehingga sistem tersebut dapat mengolah informasi untuk mendukung keputusan dengan menawarkan alternatif-alternatif solusi yang terbaik .

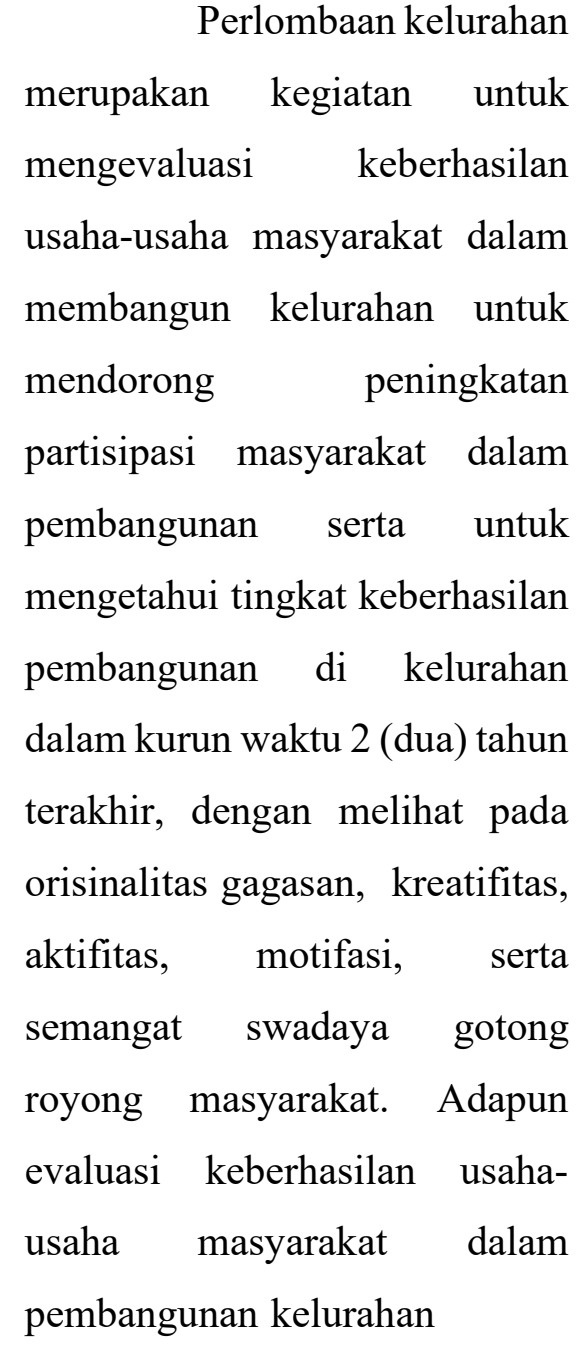


dinilai dari perkembangan beberapa aspek kehidupan masyarakat. Proses lomba kinerja kelurahan dilakukan dengan tiga jenis penilaian, yakni : seleksi administrasi, seleksi presentasi, dan seleksi kunjungan lapang. Untuk seleksi administrasi antara lain dinilai dari aspek: bidang pendidikan masyarakat, kesehatan masyarakat, ekonomi masyarakat, keamanan dan ketertiban, partisipasi masyarakat, pemerintahan desa dan kelurahan, kelembagaan masyarakat dan pembedayaan kesejahteraan kelurahan. Pada penilaian administrasi ini sudah ada aturan dan sistem tersendiri yang digunakan untuk menghitung skor hasil penilaian. Untuk seleksi presentasi dinilai dari penguasaan materi, penampilan pemberi materi, dan ketepatan waktu presentasi. Sedangkan untuk kunjungan lapang dinilai dari : produk unggulan dan inovasi dengan mengacu Permendagri nomor 13 tahun 2007 tentang pedoman penyelenggaraan perlombaan desa dan kelurahan.

Selama ini untuk memilih kinerja kelurahan mana yang terbaik dalam proses penilaian seleksi presentasi dan seleksi kunjungan lapang pada proses perlombaan kelurahan tingkat Kota Bogor, tim penilai yang dibentuk oleh Walikota Bogor masih kesulitan dalam menentukan kinerja kelurahan terbaik dikarenakan adanya perbedaan pendapat antara tim penilai satu dengan yanglainnya dalam menentukan pemenangnya .Oleh karena itu, untuk mempermudah tim penilai dalam memilih kinerja kelurahan yang terbaik dalam proses penilaian seleksi presentasi dan seleksi kunjungan lapang pada proses lomba kinerja kelurahan tingkat Kota Bogor maka perlu dibuat suatu sistem pendukung keputusan yang dapat membantu memberikan rekomendasi hasil yang lebih akurat, lebih efektif, dan lebih efisien.

Metode AHP merupakan suatu model pendukung keputusan yang dikembangkan oleh Thomas L. Saaty. AHP menguraikan masalah multifaktor atau multikriteria yang kompleks menjadi suatu hirarki. Hirarki merupakan suatu representasi dari sebuah permasalahan yang kompleks dalam suatu struktur multilevel, dimana level pertama adalah tujuan, yang diikuti level faktor, kriteria, subkriteria, dan seterusnya hingga level terakhir dari alternatif. Dengan hirarki, suatu masalah yang kompleks dapat diuraikan kedalam 
kelompok-kelompoknya yang

kemudian diatur menjadi suatu bentuk hirarki sehingga permasalahan akan tampak lebih terstruktur dan sistematis. Rumusan masalah yang akan diteliti dalam penelitian ini adalah :a) Bagimana merancang sistem pendukung keputusan lomba kinerja kelurahan? b) Bagimana mengimplementasikan metode Analytical Hierarchy Process (AHP) pada sistem pendukung keputusan lomba kinerja kelurahan? c) Bagaimana membangun sistem pengambilan keputusan untuk membantu tim penilai lomba kinerja kelurahan tingkat Kota Bogor dalam memilih kinerja kelurahan terbaik?. Tujuan penelitan ini adalah membangun suatu model pengambilan keputusan dengan mengunakan metode Analytical Hierarchy Process (AHP) untuk membantu para tim penilai lomba kinerja kelurahan dalam menentukan kinerja kelurahan terbaik pada lomba kinerja kelurahan tingkat Kota Bogor. Batasan masalah yang dibahas pada penelitian ini adalah: a) Sistem pendukung keputusan yang dibuat adalah sistem pendukungkeputusan yang hanya membantu memberikan alternatif kinerja kelurahan terbaik. b) Sampel data yang dilakukan untuk penelitian ini diperoleh dari tim penilai lomba kinerja kelurahan tingkat Kota Bogor yang terdiri dari unsur Badan Pemberdayaan Masyarakat dan Keluarga Berencana serta beberapa unsur Dinas Badan Lembaga terkait. c) Metode pengambilan data dihitung dengan menggunakan metode Analytical Hierarchy Process (AHP). d) Sistem dalam penelitian ini di buat dengan menggunakan $P H P$ dan MySQL. manfaat yang bisa didapatkan dari penelitian ini adalah: a) Bagi instansi, hasil penelitian ini diharapkan dapat menjadi masukan sebagai rekomendasi untuk tim penilai lomba kinerja kelurahan tingkat Kota Bogor dalam memilih kelurahan terbaik. b) Hasil penelitian ini juga diharapkan dapat dijadikan referensi bagi pihak- pihak lain yang berkepentingan. 


\section{METODE PENELITIAN}

Metode yang digunakan dalam pengembangan sistem dengan metode System Development Life Cycle (SDLC). Secara keseluruhan metode penelitian dapat dilihat pada pada gambar 1

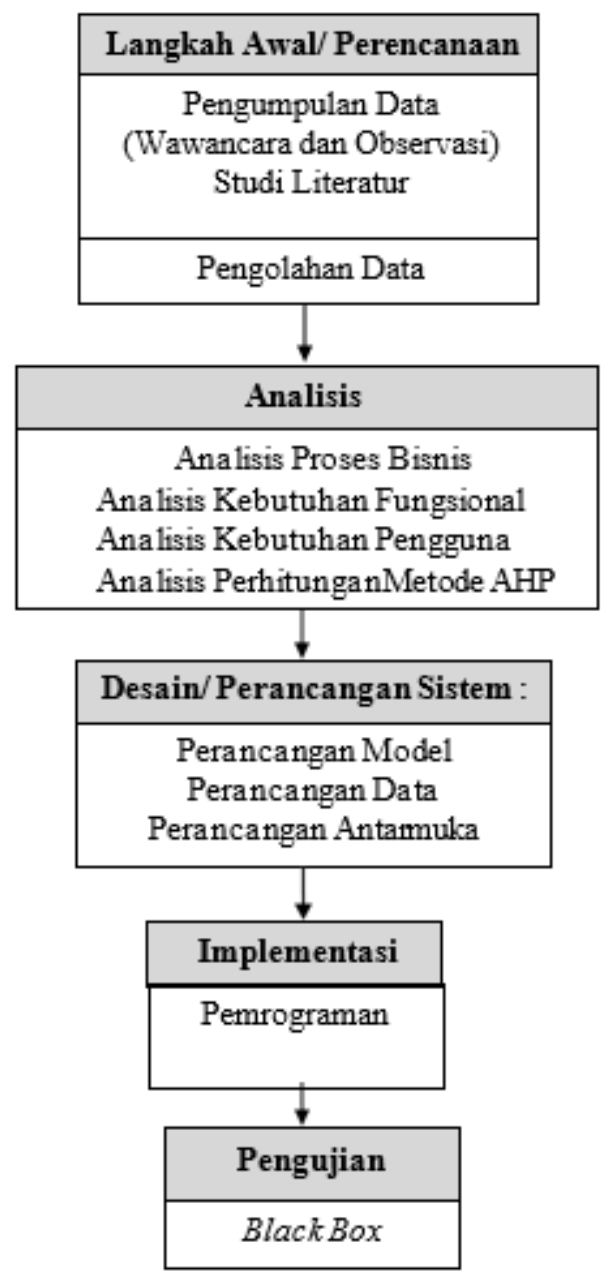

\section{Gambar 1 Diagram Metode Penelitian}

3. HASIL

\section{Analisis}

perhitungan metode AHP.

Analisis dilakukan

untuk menjelaskan

kebutuhan-kebutuhan

sistem, meliputi: analisis

proses bisnis, analisis

kebutuhan fungsional,

analisis kebutuhan

pengguna, dan analisis

\section{Analisis Proses Bisnis}

Analisis proses bisnis dilakukan dengan cara analisis proses bisnis lama dan analisis proses bisnis baru. Analisis proses bisnis menggambarkan aliran untuk mempelajari sistem yang sedang 


\section{Analisis Proses Bisnis Lama}

Analisis proses bisnis lama yang berjalan saat ini masih secara manual, dapat dilihat pada gambar 2

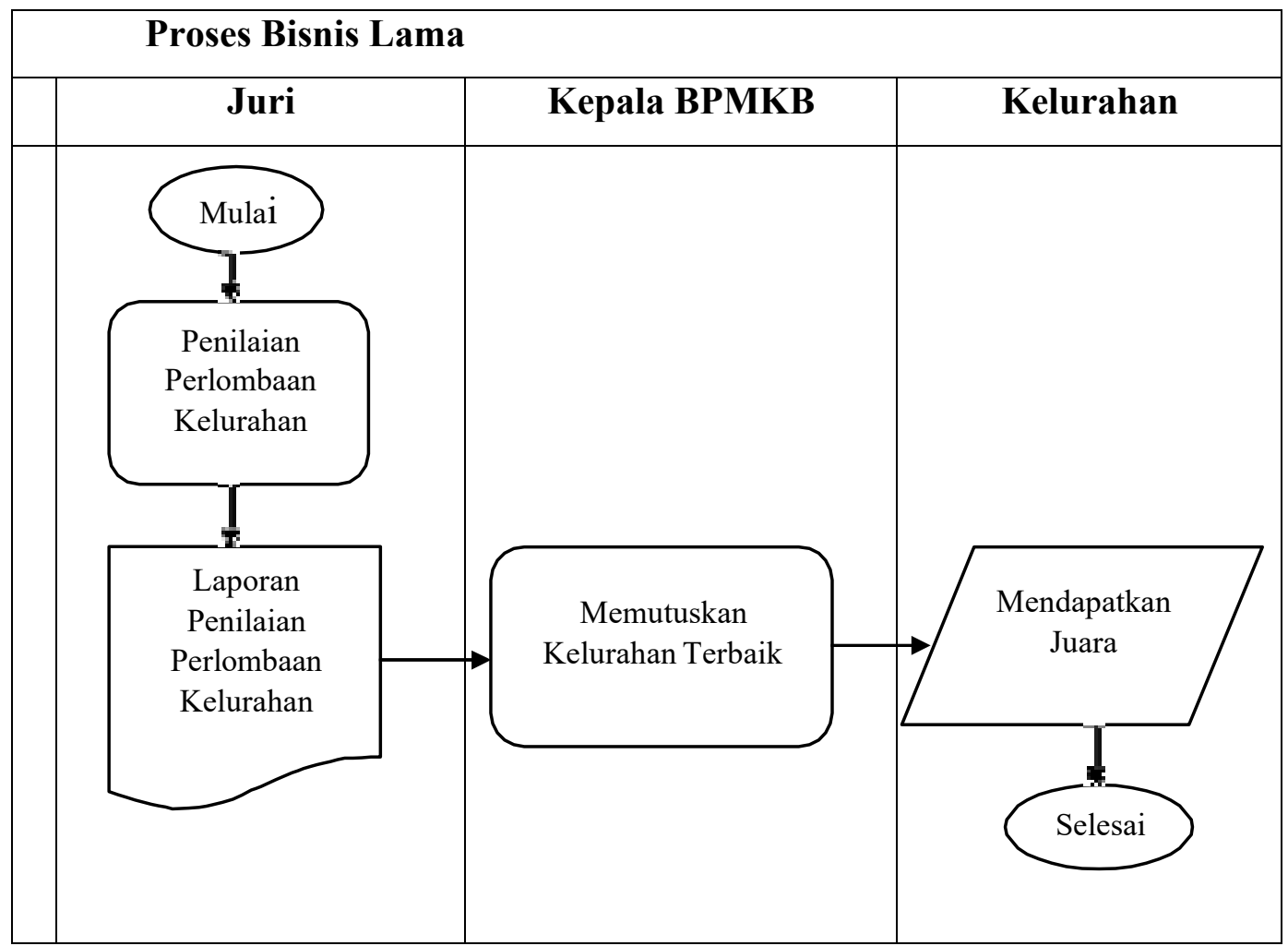

Gambar 2 Diagram Proses Bisnis Lama 


\section{Analisis Proses Bisnis Baru}

Proses bisnis baru dapat dilihat pada gambar 3

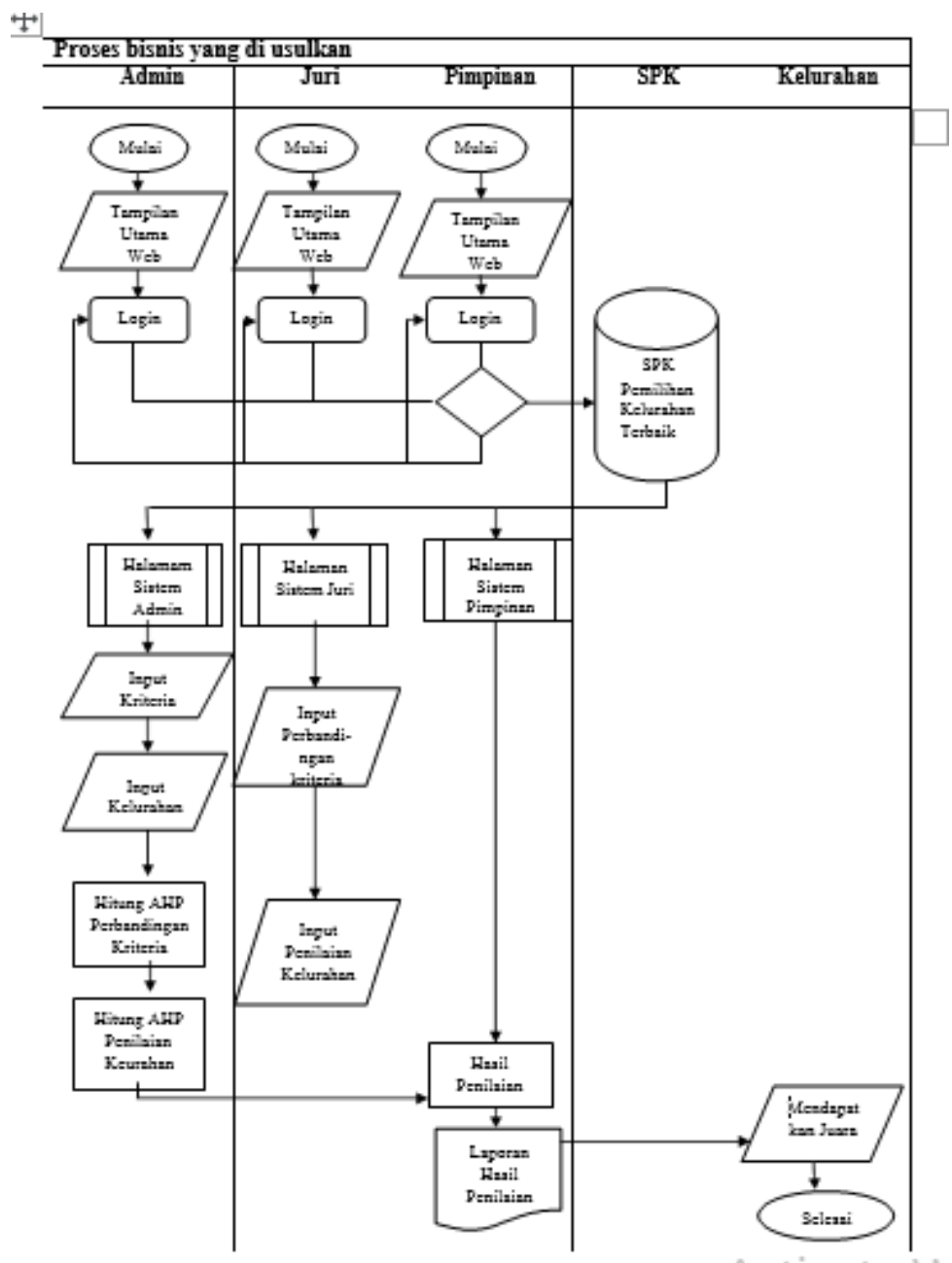

Gambar 3 Diagram Proses Bisnis Baru 


\section{Analisis Kebutuhan Fungsional}

Kebutuhan fungsional

merupakan pernyataan layanan

sistem yang harus disediakan, bagaimana sistem harus bereaksi terhadap input tertentu dan bagaimana sistem harus berperilaku dalam situasi tertentu.

Adapun analisis kebutuhan fungsional diuraikan sebagai berikut :

(1). Sistem harus dapat melakukan penambahan, dan penghapusan data kriteria maupun data alternatif.

(2). Sistem harus dapat melakukan proses perhitungan hasil kriteria maupunperingkat alternatif terbaik pada proses pemilihan kinerja kelurahan.

(3). Sistem harus dapat menampilkan dan mencetak (4). laporan hasil peringkat kelurahan terbaik dalam bentuk laporan formal.

\section{Analisis Kebutuhan Pengguna}

Pengguna sistem terdiri dari 3 pengguna, yaitu admin, juri yaitu tim penilaian lomba kinerja kelurahan dalam hal ini penginputan data alternatif dan nilai hanya diwakili oleh salah satu tim penilai lomba kinerja kelurahan yaitu Kepala Bidang Penguatan Kelembagaan dan Pengembangan Partisipasi Masyarakat pada Badan Pemberdayaan Masyarakat dan Keluarga Berencana Kota Bogor sebagai leading sektor,. Sedangkan Pimpinan merupakan Kepala dari BPMKB Kota Bogor. Kegiatan yang dapat dilakuakan user terhadap sistem, dapatdilihat pada Tabel 1

Tabel 1 Analisis Kebutuhan Pengguna

\begin{tabular}{|c|l|}
\hline User & \multicolumn{1}{|c|}{ Deskripsi } \\
\hline \multirow{5}{*}{ (Admin) } & User dapat melakukan login \\
\cline { 2 - 2 } & User dapat melakukan penambahan, dan penghapusan data kriteria \\
\cline { 2 - 2 } & $\begin{array}{l}\text { User dapat melakukan penghitungan data kriteria dan alternatif } \\
\text { User dapat melakukan pemilihan data alternatif yang telah } \\
\text { disediakan }\end{array}$ \\
\cline { 2 - 2 } & $\begin{array}{l}\text { User dapat melihat hasil rekomendasi untuk pemilihan kinerja } \\
\text { kelurahan terbaik }\end{array}$ \\
\cline { 2 - 2 } & User dapat melakukan logout \\
\hline
\end{tabular}




\begin{tabular}{|l|l|}
\hline \multirow{3}{*}{ Juri } & User dapat melakukan login \\
\cline { 2 - 2 } & $\begin{array}{l}\text { User dapat melakukan pemilihan data alternatif yang telah } \\
\text { disediakan }\end{array}$ \\
\cline { 2 - 2 } & User dapat menginput nilai perbandingan berpasangan kriteria \\
\cline { 2 - 2 } & User dapat menginput nilai alternatif berdasarkan hasil penilaian \\
\cline { 2 - 2 } & User dapat melakukan logout \\
\hline Pimpinan & User dapat melakukan login \\
\cline { 2 - 2 } & $\begin{array}{l}\text { User dapat melihat hasil rekomendasi untuk pemilihan kinerja } \\
\text { kelurahan terbaik }\end{array}$ \\
\cline { 2 - 2 } & User dapat melakukan logout \\
\hline
\end{tabular}

\section{Analisis Perhitungan Metode AHP}

\section{Pembentukan Hierarki}

Berdasarkan data yang diperoleh, maka digunakan 5 (lima) kriteria dalam perhitungan metode AHP yaitu penguasaan materi ekspos, penampilan pemberi materi ekspos, ketepatan waktu ekspos, produk unggulan, dan inovasi, dengan 6 (enam) alternatif kelurahan yang akan diberikan nilai, antara lain: Ciparigi, Menteng, Babakan Pasar, Katulampa, Cikaret, dan Cibadak. Selengkapnya dapat dilihat pada Tabel. 2

Tabel 2 Kriteria dan Alternatif

\begin{tabular}{|l|l|}
\hline \multicolumn{1}{|c|}{ Tujuan } & \multicolumn{1}{c|}{ Lomba Kinerja Kelurahan } \\
\hline Kriteria & $\begin{array}{l}\text { Penguasaan Materi Ekspos, Penampilan Pemberi } \\
\text { Materi Ekspos, Ketepatan Waktu Ekspos, Produk } \\
\text { Unggulan, dan Inovasi }\end{array}$ \\
\hline Alternatif & $\begin{array}{l}\text { Ciparigi, Menteng, Babakan Pasar, Katulampa, } \\
\text { Cikaret, dan Cibadak }\end{array}$ \\
\hline
\end{tabular}

Diagram hierarki pada metode AHP memiliki dua tingkatan, yaitu kriteria dan alternatif. Diagram hierarki seperti ditunjukan pada Gambar 4 


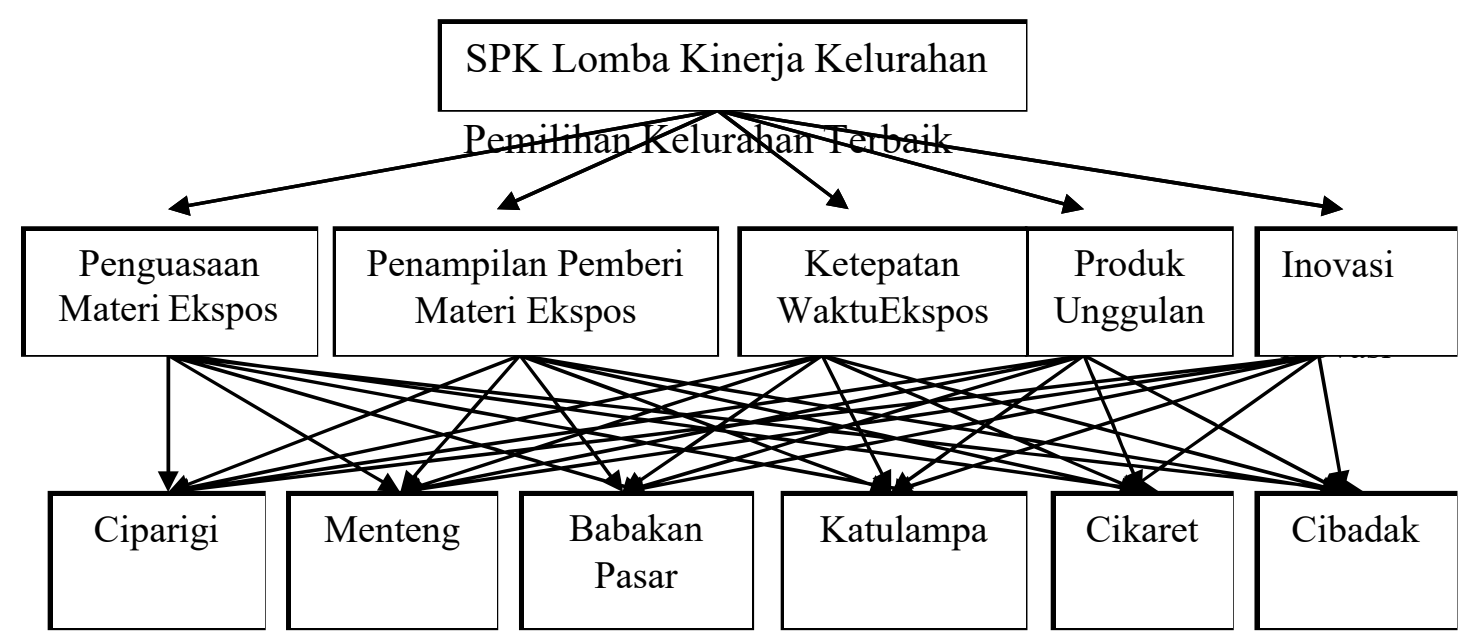

Gambar 4 Diagram Hierarki Metode AHP

\subsubsection{Menentukan Prioritas Kriteria}

Langkah-langkah yang harus dilakukan dalam menentukan prioritas kriteria adalah sebagai berikut :

(1) Memasukkan nilai perbandingan tingkat kepentingan kriteria

Memasukkan nilai perbandingan tingkat kepentingan kriteria berdasarkan penilaian yang dilakukan oleh 3 orang responden yang mewakili tim penilailomba kinerja kelurahan tingkat Kota Bogor yaitu Kepala Bidang Penguatan Kelembagaan dan Pengembangan Partisipasi Masyarakat (PK PPM), Kepala Seksi Kesetaraan pada Dinas Pendidikan Kota Bogor, dan Kepala Sub Bagian Bina Pemerintahan Kecamatan dan Kelurahan pada Bagian Tata Pemerintahan Setda Kota Bogor. Adapun perhitungan nilai respon di dapat dengan cara mengambil rata rata nilai dari semua responden dan pembulatan sepertiditunjukkan pada Tabel 4.3 
Tabel 3 Perhitungan Rata-Rata Penilaian Responden

\begin{tabular}{|c|c|c|c|c|c|c|c|c|c|c|c|c|c|c|c|c|c|c|}
\hline \multicolumn{10}{|c|}{ Nilai Perbandingan Berpasangan Kriteria } \\
\hline $\begin{array}{c}\text { Penguasaan } \\
\text { Materi Ekspos }\end{array}$ & 9 & 8 & 7 & 6 & 5 & 4 & 3 & 2 & 1 & 2 & 3 & 4 & 5 & 6 & 7 & 8 & 9 & $\begin{array}{c}\text { Penampilan Pemberi } \\
\text { Materi Ekspos }\end{array}$ \\
\hline $\begin{array}{c}\text { Penampilan } \\
\text { Pemberi Materi } \\
\text { Ekspos }\end{array}$ & 9 & 8 & 7 & 6 & 5 & 4 & 3 & 2 & 1 & 2 & 3 & 4 & 5 & 6 & 7 & 8 & 9 & $\begin{array}{c}\text { Ketepatan Waktu } \\
\text { Ekspos }\end{array}$ \\
\hline $\begin{array}{c}\text { Ketepatan } \\
\text { Waktu Ekspos }\end{array}$ & 9 & 8 & 7 & 6 & 5 & 4 & 3 & 2 & 1 & 2 & 3 & 4 & 5 & 6 & 7 & 8 & 9 & Produk Unggulan \\
\hline $\begin{array}{c}\text { Produk } \\
\text { Unggulan }\end{array}$ & 9 & 8 & 7 & 6 & 5 & 4 & 3 & 2 & 1 & 2 & 3 & 4 & 5 & 6 & 7 & 8 & 9 & \\
\hline
\end{tabular}

Berdasarkan Tabel 3 Perhitungan Rata-Rata Penilaian Responden dapat dibaca bahwa 5 kriteria tersebut diatas disetarakan dengan huruf a sampai e. dimana $\mathrm{a}=$ penguasaan materi ekspos, $\mathrm{b}=$ penampilan pemberi materi ekspos, $\mathrm{c}$ = ketepatan waktu ekspos, $\mathrm{d}=$ Produk Unggulan, dan $\mathrm{e}=$ inovasi, yang selanjutnya nilai-nilai perbandingan kriteria diatas dibuat menjadi matrik berpasangan dengan ketentuan dimana $\mathrm{A}: \mathrm{B}, \mathrm{B}: \mathrm{C}$ harus sama dengan $\mathrm{A}: \mathrm{C}$,maka tabel matrik hasil perbandingan berpasangan berdasarkan kriteria dapat dilihat pada Tabel 4.4

Tabel 4 Matrik Hasil Perbandingan Berpasangan Berdasarkan Kriteria

\begin{tabular}{|c|c|c|c|c|c|}
\hline Goal & $\begin{array}{c}\text { Penguasaan } \\
\text { Materi } \\
\text { Ekspos }\end{array}$ & $\begin{array}{c}\text { Penampilan } \\
\text { Pemberi Materi } \\
\text { Ekspos }\end{array}$ & $\begin{array}{c}\text { Ketepat } \\
\text { an } \\
\text { Waktu } \\
\text { Ekspos }\end{array}$ & $\begin{array}{c}\text { Produk } \\
\text { Unggul } \\
\text { an }\end{array}$ & Inovasi \\
\hline $\begin{array}{c}\text { Penguasaan Materi } \\
\text { Ekspos }\end{array}$ & 1 & $3 / 1$ & $3 / 2$ & $3 / 4$ & $3 / 8$ \\
\hline $\begin{array}{c}\text { Penampilan Pemberi } \\
\text { Materi Ekspos }\end{array}$ & $1 / 3$ & 1 & $1 / 2$ & $1 / 4$ & $1 / 8$ \\
\hline $\begin{array}{c}\text { Ketepatan Waktu } \\
\text { Ekspos }\end{array}$ & $2 / 3$ & $2 / 1$ & 1 & $1 / 2$ & $1 / 4$ \\
\hline Produk Unggulan & $4 / 3$ & $4 / 1$ & $2 / 1$ & 1 & $1 / 2$ \\
\hline Inovasi & $8 / 3$ & $8 / 1$ & $4 / 1$ & $2 / 1$ & 1 \\
\hline
\end{tabular}

\section{Perancangan Sistem}

\section{Context Diagram}

Context diagram merupakan DFD pertama dalam proses bisnis. Menunjukan konteks dimana proses bisnis berada. Menunjukan semua prosesbisnis dalam 1 proses tunggal (proses 0 ). Context diagram juga menunjukansemua enntitas luar yang menerima informasi dari atau memberikan informasi ke sistem. Context diagram ditunjukan pada Gambar 5 


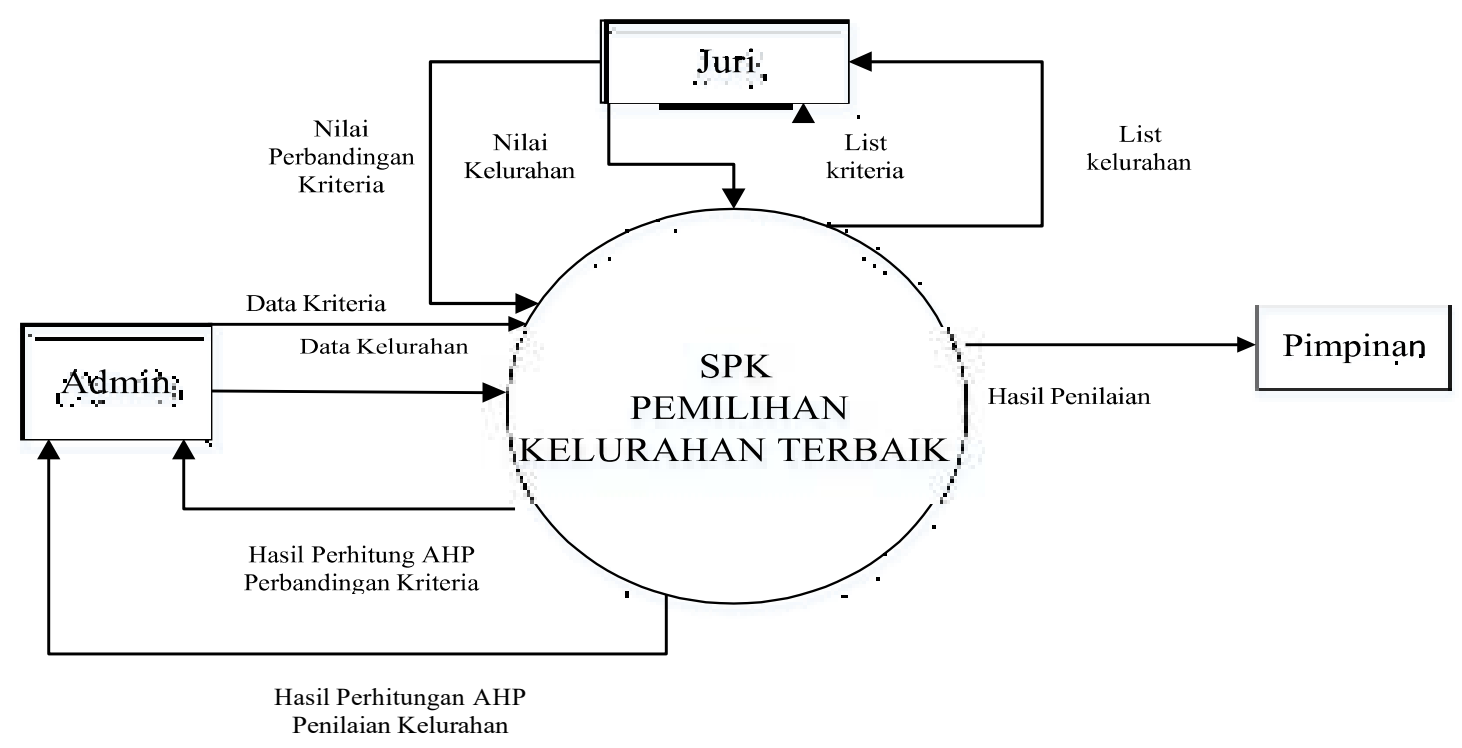

Gambar 5 Context Diagram

Cotext Diagram pada gambar 5 memberikan gambar bahwa sistem pendukung keputusan lomba kinerja berinteraksi dengan tiga entitas luar, yaitu :

a. Admin

Terdapat aliran data masuk ke sistem pendukung keputusan lomba kinerja kelurahan yaitu input kriteria dan input kelurahan dan aliran data keluar dari system pendukung keputusan lomba kinerja yaitu perhitungan AHP perbandingan kriteria dan perhitungan AHP penilaian kelurahan

b. Juri

Terdapat aliran data masuk ke SPK lomba kinerja yaitu input perbandingan kriteria dan input penilaian kelurahan dan terdapat aliran data keluardari sistem pendukung keputusan lomba kinerja kelurahan yaitu berupa list kriteria dan informasi data kelurahan yang akan dinilai

c. Pimpinan

Terdapat aliran data keluar dari system pendukung keputusan lomba kinerja kelurahan yaitu hasil rekomendasi. 


\section{Antarmuka Menu Hasil} Penilaian

Antarmuka menu hasil penilaian menampilan rekomendasi laporan hasil penilaian yang telah dilakukan juri.

Antarmuka menu hasil penilaian dapat dilihatpada gambar 6

\section{Pengujian sistem}

Pengujian merupakan suatu bagian yang penting dalam siklus pembangunan perangkat lunak. Pengujian dilakukan untuk menjamin kualitas dan mengetahui kelemahan

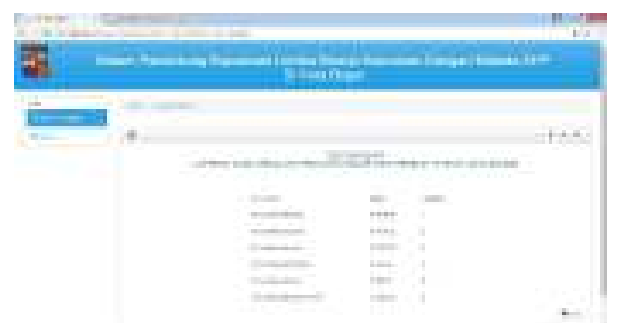

Gambar 6 Antarmuka Menu Hasil Penilaian

dari perangkat lunak tersebut. Proses pengujian menggunakan Black-box. Black-box berfokus pada fungsionalitas pernagkat lunak tanpa pengetahuan struktur internal program (source code.)

\section{Hasil Pengujian Halaman Admin}

Ada beberapa menu dari sistem yang diuji fungsionalitasnya antara lain :

\section{1). Halaman Login}

Tabel 5 Hasil Pengujian Halaman Login Admin

\begin{tabular}{|c|l|l|c|}
\hline No & \multicolumn{1}{|c|}{ Skenario } & \multicolumn{1}{|c|}{ Hasil } & Pengujian \\
\hline 1 & $\begin{array}{l}\text { Login : username dan } \\
\text { password benar }\end{array}$ & $\begin{array}{l}\text { Masuk ke halaman login } \\
\text { admin }\end{array}$ & Sesuai \\
\hline 2 & $\begin{array}{l}\text { Login : username atau } \\
\text { password salah }\end{array}$ & Tetap dihalaman login & Sesuai \\
\hline
\end{tabular}

\section{2). Halaman Menu Input Kriteria}

Tabel 6 Hasil Pengujian Halaman Menu Input Kriteria

\begin{tabular}{|c|l|l|c|}
\hline No & \multicolumn{1}{|c|}{ Skenario } & \multicolumn{1}{|c|}{ Hasil } & Pengujian \\
\hline 1 & Klik tombol tambah kriteria & $\begin{array}{l}\text { Masuk ke halaman tambah } \\
\text { kriteria }\end{array}$ & Sesuai \\
\hline 2 & Klik tombol hapus & Data kriteria terhapus & Sesuai \\
\hline 3 & Klik tombol simpan Kriteria & Data kriteria tersimpan & Sesuai \\
\hline
\end{tabular}




\begin{tabular}{|c|l|l|c|}
\hline 4 & $\begin{array}{l}\text { Klik menu kriteria, tetapi } \\
\text { kriteria sudah teriisi }\end{array}$ & Data tetap tersimpan & Sesuai \\
\hline
\end{tabular}

3). Halaman Menu Perbandingan Kriteria

Tabel 7 Hasil Pengujian Halaman Menu Perbandingan Kriteria

\begin{tabular}{|c|c|c|c|}
\hline No & Skenario & Hasil & Pengujian \\
\hline 1 & $\begin{array}{l}\text { Klik menu perbandingan } \\
\text { kriteria yang belum di isi } \\
\text { juri }\end{array}$ & $\begin{array}{l}\text { Tampil "Juri belum } \\
\text { melakukan perbandingan } \\
\text { kriteria" }\end{array}$ & Sesuai \\
\hline 2 & $\begin{array}{l}\text { Klik menu perbandingan } \\
\text { kriteria yang telah di isi juri }\end{array}$ & $\begin{array}{l}\text { Tampil matrik perbandingan } \\
\text { kriteria }\end{array}$ & Sesuai \\
\hline 3 & $\begin{array}{l}\text { Klik tomobol hapus } \\
\text { perbandingan }\end{array}$ & Perbandingan kriteria terhapus & Sesuai \\
\hline 4 & $\begin{array}{l}\text { Klik tombol hitung kuadrat } \\
\text { matriks iterasi } 1\end{array}$ & Tampil matrik iterasi 1 & Sesuai \\
\hline 5 & $\begin{array}{l}\text { Klik tombol hitung nilai } \\
\text { eigen }\end{array}$ & Tampil eigen & Sesuai \\
\hline 6 & $\begin{array}{l}\text { Klik tombol hitung kuadrat } \\
\text { matrik }\end{array}$ & $\begin{array}{l}\text { Tampil halaman kuadrat } \\
\text { matrik }\end{array}$ & Sesuai \\
\hline 7 & $\begin{array}{l}\text { Klik tombol hitung nilai } \\
\text { eigen }\end{array}$ & Tampil halaman eigen & Sesuai \\
\hline 8 & Klik tombol selisih eigen & Tampil halaman selisih eigen & Sesuai \\
\hline 9 & $\begin{array}{l}\text { Klik tombol urutkan ranking } \\
\text { kriteria }\end{array}$ & $\begin{array}{l}\text { Tampil halaman urutan } \\
\text { ranking kriteria }\end{array}$ & Sesuai \\
\hline 10 & $\begin{array}{l}\text { Klik tombol hitung weight } \\
\text { sum vector \& matriks } \\
\text { consistenci vector }\end{array}$ & $\begin{array}{l}\text { Tampil halaman weigh sum } \\
\text { vector dan matrik konsistensi }\end{array}$ & Sesuai \\
\hline
\end{tabular}

\section{4). Halaman Menu Penilaian Kelurahan}

Ada 2 fungsi pada Menu Penilaian kelurahan yaitu untuk menginput nama kelurahan dan untuk menghitung AHP penilaian kelurahan. 


\begin{tabular}{|c|l|l|c|}
\hline No & \multicolumn{1}{|c|}{ Skenario } & \multicolumn{1}{|c|}{ Hasil } & Pengujian \\
\hline 1. & Klik tombol pilih kelurahan & $\begin{array}{l}\text { Tampil nama kelurahan yang } \\
\text { dipilih }\end{array}$ & Sesuai \\
\hline 2 & $\begin{array}{l}\text { Klik tombol simpan } \\
\text { penilaian }\end{array}$ & Data kelurahan tersimpan & Sesuai \\
\hline 3 & Klik tombol hapus penilaian & $\begin{array}{l}\text { Data penilaian kelurahan } \\
\text { terhapus }\end{array}$ & Sesuai \\
\hline 4 & $\begin{array}{l}\text { Klik menu penilaian } \\
\text { kelurahan yang belum di isi } \\
\text { juri }\end{array}$ & $\begin{array}{l}\text { Tampil “ Juri belum } \\
\text { melakukan penilaian } \\
\text { kelurahan" }\end{array}$ & Sesuai \\
\hline
\end{tabular}

Tabel 9 Halaman Menu Penilaian Kelurahan 2

\begin{tabular}{|c|l|l|c|}
\hline No & \multicolumn{1}{|c|}{ Skenario } & \multicolumn{1}{|c|}{ Hasil } & Pengujian \\
\hline 1. & $\begin{array}{l}\text { Klik menu penilaian } \\
\text { kelurahan }\end{array}$ & $\begin{array}{l}\text { Tampil halaman nilai } \\
\text { kelurahan yang telah } \\
\text { diinputkan juri }\end{array}$ & Sesuai \\
\hline 2 & Klik tombol hapus penilaian & $\begin{array}{l}\text { Data penilaian kelurahan } \\
\text { terhapus }\end{array}$ & Sesuai \\
\hline 3 & $\begin{array}{l}\text { Klik tombol konversi skala } \\
\text { AHP }\end{array}$ & $\begin{array}{l}\text { Tampil nilai yang sudah di } \\
\text { konversi ke skala AHP }\end{array}$ & Sesuai \\
\hline 4 & $\begin{array}{l}\text { Klik tombol konversi ke } \\
\text { matrix }\end{array}$ & $\begin{array}{l}\text { Tampil nilai kelurahan yang } \\
\text { sudah berupa matrik }\end{array}$ & Sesuai \\
\hline 5 & $\begin{array}{l}\text { Klik tombol hitung eigen } \\
\text { kriteria }\end{array}$ & $\begin{array}{l}\text { Tampil nilai matrik yang } \\
\text { dikuadratkan }\end{array}$ & Sesuai \\
\hline 6 & $\begin{array}{l}\text { Klik tombol hitung nilai } \\
\text { eigen }\end{array}$ & $\begin{array}{l}\text { Tampil nilai eigen alternatif } \\
\text { Klik tombol kalikan dengan }\end{array}$ & $\begin{array}{l}\text { Tapil hasil rekomendasi urutan } \\
\text { ranking }\end{array}$ \\
\hline
\end{tabular}




\section{KESIMPULAN}

Dengan adanya sistem pendukung keputusan lomba kinerja kelurahan diharapkan : 1. Sistem dapat memberikan keputusan alternatif lomba kinerja kelurahan dengan menggunakan metode Analytical Hierarchy Process (AHP) yang nantinya bisa dijadikan rekomendasi untuk memilih kinerja kelurahan

\section{DAFTAR PUSTAKA}

[1]. Victor Richard;

Kemalasari N.R, Sistem

Pendukung Keputusan

Pemilihan Supplier Berbasis

Web Menggunakan Metode

AHP Pada Bagian

Kepegawaian di BPLHD

Provinsi Jawa Barat,

Bandung:PKN LPKIA.

[2]. Nasution P.P, Sistem Pendukung Keputusan

Penambahan Program Studi

Dengan Metode Analytical

Hierarchy Process (AHP),

Volume:III. Nomor: 1, Mei

2014 Majalah Ilmiah Informasi

dan Teknologi Ilmiah (INTI)

ISSN: 2339-210X.

[3]. Gunawan; Ginting Mbayak;

Halim Fandi ; Pasaribu T.A;

Purba Basri, SPK Pemilihan

Komisaris Lapangan Berprestasi

Dengan Metode AHP Studi terbaik. 2. Berdasarkan hasil perhitungan sistem diperoleh hasil perhitungan bobot kriteria tertinggi 0,4444 yaitu kriteria inovasi dan bobot kriteria terendah 0,0556 yaitu kriteria penampilan pemberi materi ekspos. Sedangkan hasil perhitungan bobot alternatif tertinggi $0,1848 \quad$ yaitu kelurahan Menteng dan bobot alternatif terendah 0,1488 yatu kelurahan Babakan Pasar.

Kasus: $\quad$ KOPDIT $\quad C U$

HATIRONGGA, STMIK

Mikrosil Medan, ISSN. 1412-

0100 Vol 16, No 1, April 2015.

[4]. Pemerintah Kota Bogor,

Renstra

Badan

Pemberdayaan Masyarakat

dan Keluarga Berencana

Kota Bogor 2016-2020.

[5]. Peraturan Menteri Dalam

Negeri Nomor 13 Tahun 2007

tentangPenyelenggaraan

Perlombaan Desa dan

Kelurahan, 2009.

[6].Kusrini, $\quad$ M.Kom, Konsep dan

Aplikasi Sistem

Pendukung

Keputusan, Yogyakarta: C.V

Andi Offset, 2007.

[7]. Prof. Dr. Ir. Marimin, 
M.Sc, Teknik dan Aplikasi

PengambilanKeputusan

Kriteria Majemuk, Jakarta: PT.

Grasindo, 2004.

[8]. Al Fatta Hanif, Analisis

\& Perancangan Sistem

Informasi, Yogyakarta: C.V

Andi Offset, 2007.

[9]. Sanjaya, "Aplikasi Sistem

Pendukung Keputusan Untuk

MenentukanTransaksi Online

Yang Aman Menggunakan

Metode Analitical Hierarchy

Process (AHP) Berbasis Web

(Studi Kasus : Forum Jual

Beli

$$
\text { kaskus)"elib }
$$

rary.

if.uinsgd.ac.id/index.php/jkate

gori/detail_file/SKSP.K0020.

[10].Hadi Irfan, Sistem

Pendukung Keputusan

Rekomendasi Pegawai

Teladan Menggunakan

Metode AHP (Studi Kasus

Di UPT Radiodan TV

Diskominfo Kabupaten

Bogor), Skripsi Universitas

Ibn Khaldun Bogor Fakultas

Teknik Informatika, Bogor,

2015.

[11]. Magdalena Hilyah ,

Sistem Pendukung Keputusan

Untuk Menentukan Mahasiswa
Lulusan Terbaik Di Perguruan

Tinggi (Studi Kasus STMIK

Atma Luhur Pangkalpinang):

Seminar NasionalTeknologi

Informasi dan Komunikasi

2012 (SENTIKA 2012).

[12]. Ardiyanto Hermawan,

Sistem Pendukung Keputusan

Pemilihan Perumahan

Menggunakan Metode AHP

Berbasis Web (Studi Kasus

$C V$. Wisma Anungkriya

Demak), Journal Of

Informatics And Technology,

Vol 2, No 3, Tahun 2013.

[13]. Rijayana Iwan ;

Okirindho Lirien, Sistem

Pendukung Keputusan

Pemilihan Karyawan

Berprestasi Berdasarkan

Kinerja Menggunakan Metode

Analityc Hierarchy Process :

Seminar Nasional Informatika

2012 (semnasIF 2012) UPN

"Veteran" Yogyakarta, 20 Juni

2012.

[14]. Herdiyanti Astri;

Widianti U.D, Pembangunan

Sistem Pendukung Keputusan

Rekrutmen Pegawai Baru Di

PT. $A B C$, Jurnal Ilmiah

Komputer dan Informatika

(KOMPUTA) Vol. 2, No.2,

Oktober 2013 ISSN : 2089- 
9033.

[15]. Tominanto, Sistem

Pendukung Keputusan

Dengan Metode Analytical

Hierarchy Process (AHP)

Untuk Penentuan Prestasi

Kinerja Dokter Pada RSUD

Sukohardjo, Volume: III.

Nomor: 1, Mei 2014 Majalah

Ilmiah Informasi dan

Teknologi Ilmiah (INTI)

ISSN: 2339-210X. 